UDC 821.161.1-Baltrush.20

DOI https://doi.org/10.32838/2663-6069/2020.3-2/29

Shcherbina $V_{\text {. }}$.

National Academy of the National Guard of Ukraine

\title{
PHONETIC EXPRESSIVE MEANS AS A FEATURE OF YURGIS BALTRUSHAITIS' POETIC WORLD IN THE CONTEXT OF RUSSIAN SYMBOLIST POETRY
}

The article is devoted to the analysis of the phonetic expressive means in Yurgis Baltrushaitis' poetic world. The tendency to abstract and disperse semantic meaning of a word defined the originality of expressive means usage in symbolist poetry. The themes, motifs, images and stylistic devices, varying in Baltrushaitis'poems, reflect Baltrushaitis'philosophic and aesthetic views.

The purpose of the article is to reveal the features of phonetic expressive means usage in Baltrushaitis' lyrics and define their role in poet's artistic world. The same emotions and moods can be seen in all poet's works. It is proved that important role in creating specific emotional colouring belongs to the original sound instrumentation. The enormous images, surrounding man in Baltrushaitis'poetic world, require specific sound images.

The instrumentation of early poems is characterized by frequent use of alliteration and sound imitative words. The alliteration may have form of phonetic anaphora and phonetic epiphora. It is shown that phonetic anaphora is used to create the common poetic key and emphasize the psychological conflict between nature and man. In Baltrushaitis'lyrics phonetic epiphora is aimed at emphasizing distinct and clear rhythm. The repeated final consonants take part in the developing lyrical plot, creating lyrical mood and tone of the poem. Such sound instrumentation can change rhythmical pattern of the lyrical narration as well as add some energy and hasten the pace of the narration.

The analysis of Baltrushaitis' artistic world shows that such kinds of sound repetitions as rondo and zeugma are used to perform aesthetic function as well as create the symmetry of the poem. More complicated forms of alliteration and its decomposition take part in forming and developing the lyrical plot of most poems

It is proved that in Baltrushaitis'lyrics the sound gamut is used for creating images of nature. The motifs and themes of poetry are in strict balance with phonetic expressive means which are often neutralized by clear and simple composition. The rhythmic pattern and the instrumentation of the poems are subordinated to the logics of poetic narration.

Key words: alliteration, anaphora, epiphora, instrumentation, gamut, lyrics.

Formulation of the problem. Russian Symbolism as a literary and artistic movement is based on certain philosophic and aesthetic ideas. In 1886 Jean Moreas, the young French poet and the author of a new literary school manifesto, emphasized that "symbolism requires the new complicated poetic style, which will be able to connect lyric idea and mysteries of universal being" [12, p. 3]. Vivid language, semantic freedom of initial words, clear rhyme and specific metrical system became significant characteristics of symbolist poetry in all European countries. Trying to understand the world of phenomena in the form of a certain spiritual idea, symbolists wanted to modernize existing poetic means. The symbolist concept of new poetic language was aimed at restoring "true magic predestination" of a word that becomes independent and many-sided. Word is viewed as the absolute, within which aesthetic unification of reality and dream may happen. According to symbolist conception, symbol is "the internal word in the external one". As a result the word absorbs all infinite and inexhaustible information about the Universe. Creating special, cult attitude to the word, symbolists were trying to transform reality.

Characterizing symbolism artistic norm the researcher N. Nezhinec points out: "Poetry of hints is characterized by so-called desemantization of words which at the same time obtain typically symbolist meanings. Due to this process words are deprive of their fettering materiality and get the shade of mysterious, elusive sense" [12, p. 35]. No wonder that in case when word meaning becomes less important, the role of sounds increases. In symbolist poetry sounds obtain new quality, they become richer and seem to be tangible. For understanding symbolist poems the way the word sounds proved to be more important than its meaning. 
The aspiration to specific euphony, to thorough word instrumentation was caused by careful attitude to word itself. The Russian Symbolists chose words basing both on semantic meanings and the way they sound. The Russian scholar M. Gasparov points out that "when just a vague halo is left of a word meaning, the phonetic, sound image of a word becomes the most significant" [27].

The new poetic language, created by symbolists, defined the typical images, key words-symbols as well as rhyme, rhythm and composition of poems. The features of symbolist philosophy were reflected in the art of selecting and combining sounds as well as in syntax, aimed at creating original rhythm and unique intonation of symbolist poetry. Various syntactic expressive means were used to show the direction of poetic movement. Capricious and changeable poetic rhythm, its unusual structure, ridiculous repetitions, vivid impressionist images have become constant characteristics of symbolist poetry, making it unique and recognizable.

Literature review. The Russian Symbolism was formed as a system of art as well as a literary school and world view. The symbolists viewed themselves as poets, philosophers and theorists. The first works, devoted to the analysis of innovative poetics, aesthetics and outlook of the Russian Symbolism, were created by the representatives of the new poetic school. The symbolists paid a lot of attention to the problem of verse phonetic organization. This question is taken into consideration in Valery Bryusov's, Konstantin Balmont's, Andrey Bely's, Alexander Blok's, Vyacheslav Ivanov's theoretical works and critical reviews. In his article "Poetry as Magic" Konstantin Balmont proves the meaningfulness of a sound in poetic speech, emphasizing the importance of instrumentation as a phenomenon. Perceiving the world as "music of all voices", Balmont underlines, that "true poet must listen to all sounds around him and try to hear the Nature and express everything he heard by means of words. Only such art can cross all limits and boundaries and open the unity of the world before man" [2, p. 300].

Yurgis Baltrushaitis, the Russian poet of Lithuanian origin, whose works demonstrate interaction of two different cultural and poetic traditions inside one artistic system. Baltrushaytis' artistic world was analyzed in the works, written by coryphaei of the Russian Symbolism. The poet's original artistic world was highly appreciated by many Russian symbolists.

V. Ivanov, the representative of the younger generation of symbolists, gave the detailed analysis of Baltrushaitis' poetic world and justified his right for the sort of activity Baltrushaitis was devoted to. V. Ivanov was the first to pay attention to the way the poems sounded, comparing them with fugue, performed by the organ in the church. Specific instrumentation reminds of a prayer and religious hymns. "In poetic speech Baltrushaitis is majestically simple, rather conservative and steady in his choice of rhymes. His verse has rather vague timbre, it is sonorous, strict and brightly instrumented" [11, p. 97]. Careful observations, made by Ivanov, gave the opportunity to imagine Baltrushaitis-poet as well as Baltrushaitis-person.

The next period of studying Baltryshaitis' poetic world started only in the 1980-s, when the first monograph, devoted to his poetry, was written by V.Dauyetite [8]. The Lithuanian researcher analyses poet's personality, his aesthetic and philosophic views, takes into consideration some features of his artistic world. Paying attention to special mood, typical of Baltryshaitis' poems, their light lyricism, the scholar explains the originality of Baltryshaitis' artistic world by poet's specific attitude to sounds. In researcher's opinion, "the originality of emotional colouring is caused by melodiousness of poet's figurative word" [8, p. 204].

The Russian scholar O. Yepisheva [9] analyses the interconnection between symbolist poetry and the music works of A. Skryabin, the famous Russian composer, pianist and pedagogue. "The correlation of A. Skryabin and symbolists leads to better understanding symbolists' attitude to the way words sound. The comparison of poetic and music art broadens the conception about possibilities of poetic word" [9, p. 139].

In spite of the growing interest to Baltryshaitis' poems, there are only few researches, devoted to analysis of the separate aspects of poet's artistic world.

The purpose of the article is to reveal the features of phonetic expressive means and stylistic devices in Yurgis Baltrushaitis' artistic world, to outline the similarity and difference in their use in Y. Baltrushaitis' poetic works in the context of the Russian Symbolists of older and younger generations. The analysis of sound phenomena in Y. Baltrushaitis' poems will give the opportunity to evaluate the original poetic atmosphere and musicality of figurative word as well as to define more exactly the poet's position both in the history of the Russian Symbolism and in the 20-th Century Literature.

Outline of the basic material. Characterizing the sound organization of Baltrushaitis' poems 
V. Dauyetite pays attention to its strict and powerful expressiveness. The peculiarity of Baltrushaitis' evolution as a poet was in consecutive use of the same themes and problems. The certain moods, emotional experiences and feelings pass through all his creative work. The main images are repeated, varied, developed, come from one poem to another. The poet's artistic world seems to be boundless and deserted. In Baltrushaitis' poetic world the man is viewed as a pilgrim and human life is identified with travelling. The story of the lyrical character is the story of his inner life, his soul and spiritual growth. He is trying to find harmony, to comprehend the mysteries of earthly being. The enormous images, surrounding man in Baltrushaitis' poetic world, require specific sound images. The lyrical plots of poems resemble pictures, which are more emotionally filled than visible. The intonational richness of sounds leads to its better perceptibility. The lyrical character is a philosopher of nature, he is depicted in his interrelation with space. Most of Baltrushaitis' poems are based on the idea of constant motion. The man's way starts on spring morning. In early poems man admires and worships nature. The lyrical character is viewed as an ideal observer, who doesn't experience discord with nature.

The Russian scholar V. Zhirmunskiy points out, that "instrumentation is a structural component of a poem, connected with intonation, vocabulary and syntax. Instrumentation includes alliteration, assonance and sound imitation. The accumulation of the homogeneous sounds (consonants or vowels) is reflected in the entire system of verse" [10, p. 121]. The specific selection of sounds in poetry can produce the certain artistic and expressive effect. The main components of euphony are sound repetitions. "Such repetitions don't mean real repetition of some facts, they contribute to accumulation and increase of emotional impressions", - writes V. Zhirmunsky [10, p. 61].

Let's consider the role of phonetic expressive means in Baltrushaitis' artistic world. The instrumentation of early poems is characterized by frequent use of alliteration and sound imitative words.

"List ne drognet v rovnom znoe, / Ni uzorchataya ten.../ Vdol tropinki nezabudki pritailis v polumgle, / Zolotye promezhutki protyanulis po zemle.../ Tolko zvonko zakhokhochet ptica $\mathrm{v}$ zeleni vetvey" ("V Lesu") [1, p. 34].

The music of sound is combined with the colour. The repetition of voiced consonant $[z]$ emphasizes the lyrical character's spring mood. The nature seems to be ready to open its mysteries to the man, who tries to peer into each flower, to scrutinize each blade. The alliteration, based on the consonant $[z]$, makes the picture of the forest both visible and audible. The repetition of the consonant $[z]$ rouses associations, connected with a hot summer day and bright green vegetation. The green colour is named in the poem only once but it seems to occupy all the space around. The lyrical character is shown at the moment of his communication with the nature. The light colouring reflects the character's tranquility and peace of mind. The nature in early poems is viewed as the landscape of the lyrical character's soul. The repeated consonant $[z]$ becomes both the sound image and the symbol of carefree period of lyrical character's life.

"Vstrepenulsya zaliv - vyrastaet volna, / Zagremela v neistovstve dikom, / I razbilas, kak zvonkiy sosud, tishina / V likovanii utra velikom". ("Utrenniye Pesni") [1, p. 32].

The poem is full of joyful energy. The space is full of cheerful sounds. The alliteration, used in the poem, underlines the pictorial image and helps to feel the melody of the morning. The lyrical narration is given with emotional intensification. All the images are moving in the same direction, to the culmination and lyrical result.

In A.Blok's poem "Gamayun, Ptica Veshchaya" the repetition of consonant $[z]$ has a different character. The theme of tragic events in the history is intensified by the use of alliteration. In this poetic context the words with negative meanings contain the consonant $[z]$. The poet influences the readers both by semantics and emotionally coloured sounds.

"Veshaet igo zlyh tatar, / Veshaet kazney ryad krovavyh, / I trus, i golod, i pozhar, / Zlodeev silu, gibel pravyh" ("Gamayun, Ptica Veshchaya") [4, p. 19].

In A. Bely's poem "Argonavty" consonant $[z]$ sounds enthusiastically. This consonant is connected with the mythological image of golden fleece (zolotoy runo), significant in poet's artistic world.

"Zovet za soboyu staric argonavt, / Vzyvaet truboj zolotoyu, /Za solncem, za solncem / Svobodu lyubya..." (“Argonavty") [3, p. 53].

The alliteration, accompanied by stressed vowels [o], creates the certain pithy melody, built in appropriate tone. The poem looks like ecstatic appeal to fly to the sun. The ideas of man's craving for height, for reaching spiritual summit, his aspiration for revealing mysteries of being are reflected in the poem.

The idea of constant motion is realized and concretized in lyrical plot of Y. Baltrushaitis' poetry, which is viewed as the story of the spiritual 
growth and development of the same lyrical character. The verses in two collections of poems "Earthly Steps" ("Zemnye stupeni") and "Mountainous Path" ("Gornaya Tropa") are united by the common lyrical plot. The poet correlates different stages of lyrical character's life with certain season in the first book of poems and with the time of the day in the second book. As it is mentioned above, the repetition of consonant $[z]$ is characteristic of man's youth, when he just starts his spiritual searches. The position of the ideal observer is changed by understanding contradictions of human life and loss of original entirety. The image of lyrical character becomes more complicated. The nature becomes indifferent and hostile to man. The alliteration, based upon repetition of voiceless consonant [p] becomes more frequent.

"Ni maloy iskry, ni cvetka / Naskolko vidit glaz, / Prishla pora pustynnaya, / Dnevnoy pozhar pogas!" ("Pozdniye Dumy") [1, p. 73]. The lyrical character is anxiously peering into the sad autumn nature, but it moves aside and leaves man alone with his bitter thoughts. Phonetic anaphora is used to create the common poetic key and emphasize the psychological conflict between the nature and man, who feels aloofness of nature and aspiration to it.

"Pust, v chastykh pytkakh ponikaya, / Sirotstvuet i plachet grud, / No sluzhit tajne bol lyudskaya, / I put terzaniy - bozhiy put" (“Zapoved Skorbi”) [1, p. 221]. In this poetic context the lyrical character is seen enriched by understanding the tragedy of earthly being. The accumulation of sound $[p]$ is used to express volitional force and energy of persuasion. This force is addressed to the lyrical himself, not to someone else. The consonant $[\mathrm{p}]$ in some way becomes the symbol of necessity to overcome hardships on man's way to harmonious heavenly world.

The use of alliteration in the poem "Razdumye" creates the specific emotional colouring. The repetition of several sounds contributes to lyrical increase of feelings. The alliteration is combined with assonance based on the vowel $[\mathrm{u}]$. The repetition of the vowel $[\mathrm{u}]$ leads to intensifying gloomy atmosphere of the narration. The instrumentation can help the reader easily imagine the lonely, almost dead tree with blackened branches, the symbol of inevitable and helpless old age. The accumulation of consonants $[\mathrm{s}],[\mathrm{k}],[\mathrm{v}]$ makes reading more difficult and reflects physical suffering of the willow tree, the symbol of the last period in a human life.

"A tam, v $u$ gry $u$ miy chas $u$ shcherba, / Skvoznym skeletom $v$ stanet verba / Sred pustoshi bez r $u$ bezha..." ("Razdumye") [1, p. 222]. The consonant [v], added to the verb, changes the tone of the narration. The psychological conclusion of the poem sounds in more optimistic way: life is impossible without struggle. In poet's opinion, man should appreciate every moment of joy and every grain of happiness.

The combination of sounds $[\mathrm{v}]$ and $[\mathrm{s}]$ is often used for revealing philosophic thoughts of the lyrical character. Such combination is repeated and united line by line in the poetic narration, which obtains dynamism and motion.

"Kak razdumye $v$ serdce mirnom / V svetlom more val vstayot, / O velicom, o vsemirnom / Dole budnechnoj poyot" ("Akkordy") [1, p. 35]. The lyrical character is shown at the moment of meditation. The hero is deeply abstracted in some lofty thoughts. The instrumentation in this poem is the component of the motive and is viewed as thematically and compositionally significant.

The repetition of voiced consonant $[\mathrm{v}]$ is often met in the poems of declarative and deductive character. In the poem "Khvala Rabam" the alliteration makes the introductive lines of the narration sound more solemnly and nobly. The theme of the artist's duty is realized in the poem. In Baltrushaitis' opinion, the true artist must work and prepare for creative activity. The art is connected with morality. The poet considers duty to be artist's volitional effort and inner need.

" $V$ borbevekovvelikvashdolgsuroviy,//lachashchie yarmo zemli serdca,/ Bezbolnye izbranniki Khristovy, $V$ cepyakh truda spodvizhniki Tvorca!" ("Khvala Rabam") [1, p. 195]. Baltrushaitis' aesthetic views are reflected in the poem. The image of artist and the image of ploughman are united. Both men are creators. The artist's predestination is to clarify chaos and to transform life aesthetically and morally. The tiller's task is to support and preserve the life. In the final lines of the poem the accent is still made on the repetition of the consonant [v]. The final accord sounds in a light and solemn way.

"No na zemle lish vami vremya krepko, / Iz vashikh slez vozniknut zhemchuga ...." ("Khvala Rabam") [1, p. 195].

In Baltrushaitis' lyrics man is viewed both as a pilgrim and creator. The idea of eternal and unchangeable value of life, full of physical and mental work, can be heard in many poems. In the poem "Stuchis, Uporstvuya, Kirka" the repetition of consonant $[t]$ gives the opportunity to feel lyrical character's painful and hard perception of the outer world. The combination of consonant [ $t$ ] with hushing sounds is used to emphasize hardships on man' way. The unlimited possibilities of human will, infinity of creative hope are proved in this poetic context. 
"I ty lish znaj,lish krotko ver, / Chto v mire prakha i poter / Tvoy trudniy trepet tolko dver ..." ("Stuchis, Uporstvuya, Kirka") [1, p. 209].

The lyrical character tries to find his personal way and comes to understanding that creative work can be the foundation of life and earthly being itself. In the final lines of the poem the accumulation of voiced consonants [d] and [v] makes the poem sound cheerfully and optimistically.

"Tvoy drevniy zvon - tvoy zhrebiy ves, / A sbudetsya sred zvyozd ne dnes, / Chto ty uporno stroish zdes ..." ("Stuchis, Uporstvuya, Kirka") [1, p. 209]. The repetition of the sound [o] sounds like sigh. The assonance at the end of the poem looks as if the narration is abruptly broken off. The lyrical character's way goes on. In his spiritual searches man cannot stop, he must always go ahead.

In Baltrushaitis' poetry alliteration may have form of phonetic epiphora. The repetition of consonants at the end of words is not very frequent in poet's artistic world but each example of its use imparts specific dynamism to lyric narration. In the poem "Detskiye Strakhi" the phonetic epiphora helps readers to see the mysterious hostile world of a sleeping house with child's eyes. The accumulation of consonant $[t]$ at the end of verbs implies child's fear and nervousness. "Kto-to sharit, roet, glozhet, / Brodit, kradetsya v tishi, / Otgonyaet i trevozhit / Sladkiy, krotkiy mir dushi!" ("Detskiye Strakhi") [1, p. 55]. At night everything seems different and full of mysteries. The life of the house, which seems so ordinary at the day time, turns out to be secretive. In this lyrical context the verbs, which are stylistic synonyms, are arranged so that each of them increases the emotional tension of the narration. The phonetic epiphora, used in the poem, contributes dynamism to the lyrical plot as well as helps to create the specific mood which causes sympathy and emotional response. The repetition of final consonants reminds beating of a frightened child's heart.

The repetition of final consonants can be used for creating the image of time. The poetic narration in the poem "Razdumye" is formulated according to the principle of inner semantic gradation. The lyrical plot is gradually revealed and emotionally intensified. "Dlitsya chas, struit, toropit vodomyot, / Seyet, stroit, zhnet i kopit vosk i myod..." ("Razdumye") [1, p. 169].

The verbs with repeated sound [t] are placed close to each other without leaving space for other sounds. The accumulated words are alike in character and emotional colouring. Time is viewed as powerful force which fills man's being with various events.
The repeated consonant $[\mathrm{t}]$ is important characteristic of the image of time, which at first appears to be generous and kind to man. The theme of Higher Forces is accompanied by the repetition of the consonant [1]. The change of sound instrumentation causes the change of the lyrical tone. The new lines sound like warning to the carefree man. The atmosphere of anxious wait and invisible threat can be heard in the final lines of the poem. "No Stroite $l$ dney ischislil ne na vek, / Chto sodeyal, chto zamyslil chelovek ..." ("Razdumye") [1, p. 169].

In Baltrushaitis' lyrics phonetic epiphora is aimed at emphasizing distinct and clear rhythm. The repeated final consonants take part in the developing lyrical plot, creating lyrical mood and tone of the poem. Such sound instrumentation can change rhythmical pattern of the lyrical narration as well as add some energy and hasten the pace of the narration.

As it is mentioned above, the repetition of consonant [ $t$ ] can impart the poem additional energy and can make it sound faster. In the poem "Vecher" we can see the opposite situation. The repetition of final consonant $[t]$ slows down the development of lyrical plot. Baltrushaitis uses the phonetic epiphora to create the image of gloomy sunset. In this poetic context the accumulation of sound $[t]$ seems to slow down the narration.

"Vechernee zarevo merknet, skudeet, / Lozhitsya tuman na polya... / I bednoe serdce drozhit kholodeet, / I glukho bezmolvna zemlya..." ("Vecher") [1, p. 76]. The sound instrumentation is based on repetition of consonant $[\mathrm{t}]$ and vowel [e]. The repetitions are important for creating the strained atmosphere. The idea of man's loneliness and helplessness is expressed in the poem. The repeated sounds unite words, closely connect and prolong poetic lines. The lyrical character feels especially sad and abandoned. The world around him looks boundless and enormous. The poem has some elegiac colouring. The combination of phonetic epiphora with voiced consonants [d] and [g] intensifies the idea about impossibility of overcoming restraint of human being in the Universe. The desolate landscape is the ideal place for learning the original essence of being. The image of sunset is frequent in Baltrushaitis' lyrics. The sunset is viewed as some crisis state of nature. The transit from one stage of a day to another one is connected with the idea of death and revival. The day is drowned and perishes in the darkness of night. The idea of sacrificial suffering for the sake of life continuation can be heard in this repeating drama.

The Russian scholar A. Gerbstman classifies sound repetitions into "anaphora, epiphora, rondo 
and zeugma" [7, p. 176]. The analysis of Baltrushaitis' artistic world shows that rondo (joint) and zeugma (ring) are as a rule used in combination with the other two forms of instrumentation. Such combinations perform aesthetic function as well as create the symmetry of the poem.

In the poem "Treshchina" the poet uses the combination consisting of anaphora, zeugma androndo."Izbushkavethayazanim,/Gdeyabylblizok, byl lyubim... / No uznik tam davno zabyt... / Tuda drugomu vkhod otkryt..." ("Treshchina") [1, p. 75].

The use of anaphora and zeugma emphasizes the lyrical character's sorrow, his regrets about the past and lost happiness. The instrumentation with the use of voiced consonant [b] and the sonorous [1] corresponds to the atmosphere of dismay and despair, created in the poem. The repetition of the consonant [d] in the initial and final positions causes difficulty of pronunciation and stresses the impossibility to go back to the previous life. The sound combination in the final line seems to close the precious door before the lyrical character and open it before his rival.

In the poem "Alleya" the anaphora sounds like the characteristic of the lyrical hero, while the rondo is used for creating landscape image. The repetition of the consonant [p] reminds of traveller's tiredness on a hot summer day, merciless sun and dry road dust, covering everything around. The elegant rondo is used for creating the image of cypress and imparts logical completeness to the lyrical plot. The repetition of the consonant [s] intensifies the sensation of boundless, all-absorbing silence, reigning in the land of eternal calm, the traveller reached at the end of his hard way. "K ive $p$ lakuchey putnik prishel.../ Dlitsya alleya pod goru vniz, / Gde lish cherneya spit kiparis..." (“Alleya”) [1, p. 151].

Both zeugma and anaphora are based on the repetition of the consonant [s] in the poem "Dym", devoted to the Russian composer A. Skryabin, who was for Baltrushaitis the example of true artist and creator, capable of changing the world with the help of art."Mig i vek struya svyataya / Dlit svoy tok zhivoy, / Stroyas k solncu, reya, taya, / Slivshis $s$ sinevoy..." ("Dym") [1, p. 122].

The motifs of the true artist's destination and duty can be heard in the poem. On his way in searching sense of living and truth the lyrical character is accompanied by such important attributes as svet (light), solnce (the sun), sineva (the blue). The accumulation of the sound [s] in various positions creates the atmosphere of free flight. The lyrical character's look is moving vertically towards the sun and his heart is longing for unearthly world.
The idea of impossibility to reach the completeness of being either in the earthly world or in the inaccessible and mysterious heavenly world can be heard in the poem "Zhertvennik". Anaphora and zeugma are used for creating the images of two important stages in the lyrical character's life. The repetitions of the consonants [s] and [v] in combination with the vowels [o] and [e] create the certain harmony. The use of specific instrumentation is aimed at expressing the lyrical character's belief in artist's immortality and ability to create new life. In the earthly world man's life gets significance only if he is ready to sacrifice it. The poet's aesthetic and philosophic views are reflected in the poem. The idea of the necessity to get ready for creative activity is expressed in the poem.

"Chto dolg ognya - yedinoye zveno, / $V$ tkan vechnosti vpletayushcheye nas. / Vot pochemu, prozrev $v$ lyudskom bredu, / Svoy tayniy svet, kak kazhdiy chas byloy, / $\mathrm{Na}$ zhertvennik suroviy ya kladu" ("Zhertvennik") [1, p. 199].

V. Bryusov, the representative of the older generation of the Russian symbolists, one of the founders of the "new art" in his article "Zvukopis Pushkina" describes more complicated forms of instrumentation. The famous critic and the theorist of the Russian Symbolism classifies alliteration into: posledovatelnaya (successive), preryvnaya (interrupted), obratnaya (reverse), perekrestnaya (cross) and obkhvatnaya (enfoloding) [5, p. 177]. The analysis of Baltrushaitis' lyrics shows that reverse alliteration, when sounds are repeated in the reverse order, and cross alliteration, in which "first appears one sound, then another, then the former and the latter", are more frequent in poet's artistic world. Let's consider some examples of reverse alliteration.

"Pridyot groza, zavoyet i narushit / Zemnuyu tish, - / No tishiny, chto nashe serde dushit / Ne vozmutish..." ("Alkaniye") [1, p. 68]. In the poem "Alkaniye" the reverse alliteration increases sound expressiveness and lyrical effectiveness of the poetic plot. The lyrical character is eager to conceive the unity of nature being and human life. The reverse alliteration is accordant to Baltrushaitis' favourite motif of silence. The silence in this lyrical context seems transparent but firm. The true pain of spiritual experience, gained by man on his way to understanding wisdom of nature, is hidden behind the silence. The selection of sounds in the reverse alliteration seems especially significant as their combination fills the space with additional silence. 
Philosophic reflection on irreversible time motion can be heard in Baltrushaitis' poem "Karusel". The image of time is viewed as the attribute of Higher Forces involving all human beings in the endless rotation. The mysterious merry-go-round illustrates the motif of eternal return, frequently met in poet's artistic world. Man's fate is determined by the Higher Forces. People are surrounded by impenetrable pressing circle.

"I poyot im bespreryvno zov sharmanki zaunyvnoy, / Khriploy zhaloboy zvenya.../ I ot pesni odnozvuchnoy/Chasto-chasto, v chas dokuchniy,/Rycar valitsya s konya..." ("Karusel”) [1, p. 131]. The reverse alliteration, based on repetition of the sounds $[\mathrm{z}],[\mathrm{o}],[\mathrm{v}]$, intensifies the oppressive feeling. The dramatic atmosphere of confined space is created in the poem. The alliteration brings the words together giving the lyrical context particular integrity. The reverse repetition of $[\mathrm{z}],[\mathrm{o}],[\mathrm{v}]$ supplements the visual image with the powerful sound image. The simple and dismal music of the street-organ is associated with the frightening unearthly world. Although the word zov is not used in the poem, the combination of [z], [o], [v] sounds like echo constantly calling the lyrical character.

In his lyrics Baltrushaitis often uses the reverse alliteration based on repetition of the sounds [s], [v], $[\mathrm{e}],[\mathrm{t}]$ as if filling the poetic world with additional light: "Moy siniy khram za tuchami, / Gde svetel ves proctor" [1, p. 35].

"Kak razdumie v serdce mirnom / V svetlom more val vstaet..." ("Akkordy") [1, p. 37]. Claiming that man's way in the earthly world is painful and hard, feeling the tragic nature of being, Baltrushaitis fills the boundless space of his poems with quiet warm light, which appears to be soft and hopeful.

The examples of the reverse alliteration can be noticed in creative activity of other symbolists. In the early A.Blok's poem "Ty Proshla Golubymi Putyami..." instrumentation consists of repeated sounds $[\mathrm{b}],[\mathrm{o}],[\mathrm{g}]$. The reverse alliteration intensifies the feeling of irreality of the plot. The lyrical character is ready to oppose the ominous darkness. His feat is the feat of the soul, belief in God and devotion to the ideals of Eternal Femininity.

"Nad tvoey goluboyun dorogoy / Protyanulas zloveshchaya mgla / No s glubokoyu veroyu v Boga / Mne i temnaya cerkov svetla" [4, p. 112].

The cross alliteration, in V. Bryusov's opinion, "more complicated and elegant" can be seen in Baltrushaitis' poetic works more often, than in artistic world of other symbolists. In the poem "Blednaya Skazka", one of few examples of poet's love lyrics the cross alliteration is used for describing night landscape at the beginning and at the end of the poem:"Tikho pelo vremya...
V mire noch byla / Blednoy lunnoy skazkoy laskova svetla" ("Blednaya Skazka") [1, p. 81]. The poet creates romantic picture of warm moonlit night. The cross alliteration defines the specific rhythmical pattern of the poem. The lyrical character's story sounds trustingly and intimately. In the final lines of the poem cross alliteration together with epiphora intensifies the impression of bitter loss and imparts the logical completeness to the lyrical plot: "V nebe bylo mnogo belykh motylkov / Medlenny $k h$, kholodnykh, myortvy $k h$ ogonkov" [1, p. 82].

The theme of fragility and short duration of earthly fame is revealed in Baltrushaitis' poem "Na pole Vaterlo". The poet opens before our eyes the picture of enormous plain Waterloo, where only the rustle of grass can be heard and the herd of cattle can be seen. Nothing reminds of the final fierce battle, which decided the future of Europe as well as the whole world.

"Gde grozno smert gnala svoyu metel / Teper pastukh poyot v svoyu svirel" ("Na pole Vaterlo") [1, p. 91]. The poem sounds solemnly and resembles the classical ode. The combination of the cross alliteration with other forms of instrumentation is used to reproduce the image of the cruel battle that put an end to the Napoleonic wars.

In the article "Zvukopis Pushkina" V. Bryusov describes the decomposition (razlozhenie) of alliteration, "when a word contains a complex of sounds and the same sounds are separately used in the nearest words" [5, p. 181]. V. Bryusov singles out summarizing (summiruyushchaya), detailing (detaliziruyushchaya) and amphibrach (amfibrakhicheskaya) types of decomposition of alliteration [5]. The examples of all three types of this phonetic expressive means can be found in Baltrushaitis' lyrics. The summarizing decomposition of alliteration, "when the word in which repeated sounds are united, are put after the words where these sounds are in separate positions", is used in the final lines of the poem "Odinochestvo", devoted to the problem of disconnection of people in the earthly world and necessity of searching the integrity of being. The alliteration in this lyrical context is aimed at the emphasizing the idea of man's loneliness. "Na vsekh tkachey odin stanok, / No kazhdiy sir I odinok" ("Odinochestvo") [1, p. 88].

The example of detailing decomposition of alliteration, when "the word, combining repeated sounds, is put before the words, in which these sounds are separated", we can see in Baltrushaitis' poem "V Parke": "Dazhe tam, gde v polden zharkiy / Chas prokhladniy ne skudel..." ("V Parke") [1, p. 69].

In the poem "Nohyu" the amphibrach decomposition of alliteration, "when the word in which repeated sounds 
are joined in the complex, is put between the words with the same sounds", is used for creating night landscape. The lyrical character, suffering from insomnia, is surrounded by the hostile unknown world. The specific instrumentation intensifies the feeling of sacred horror creeping over the man before the mysterious abyss, opening at night. "Ne znaya yavi, chuzhiy snu, / Ya bez opory bez zashchity / V polnochnom omute ton $u$ " ("Nochyu") [1, p. 158]. Such forms of instrumentation as decomposition of alliteration can decorate image and emotional colouring of a poem as well as determine its composition and rhythmical pattern.

In A. Gerbstman's opinion, "the most organized and more frequently used kind of instrumentation is sound gamut, which is formed by repetition of sound combination consisting of a vowel and a consonant, one of them is constant and another one is variable" [7, p. 181]. In Baltrushaitis' lyrics the sound gamut in combination with onomatopoeic words are used for creating images of nature, which is especially interesting for the poet in terms of philosophic reflection. Autumn nature occupies the most significant place in Baltrushaitis' poetic world. "Tak, tochno na mezhe osenney, / Ne shepchet veter v kamyshe, / I lish stoyat nemye teni / V iznemogayushchey dushe" [1, p. 244].

"Sred pustoshi bez rubezha, / Gde lish protyanetsya mezha / Shursha redeyushchey shchetinoy" [1, p. 222].

Feeling fragility of his life, the lyrical character is seeking constant and eternal things in nature. There are no bright landscapes in Baltrushaitis' lyrics, only some soft shades, emphasizing empty space and autumn coolness. In poet's artistic world the most frequently used sound gamut consists of vowels and sibilants. "Lish slyshu ya shorokh osenniy pechali / Nemolchnoy v zaglokhshem krugu... / I listya opali, i mertviy ikh vorokh / Vstrechayu na kazdom shagu..." ("Put k Sineve") [1, p. 139]. The prevalance of sibilants in various phonetic positions appears to reflect the lyrical character's sadness and loneliness. The sound gamut, based on sibilants, is connected with the motif of silence, one of the most productive in Baltrushaitis' poetry.

The sound gamut on voiced consonant $[b]$ is used in the poems in which apocalyptical motifs can be heard. In the poem "Venchanie" the repetition of sound $[b]$ in combination with different vowels seems to open before us the boundless white fields. The Biblical motifs are combined with traditional images of winter nature. The accumulation of the consonant [b], aimed at creating the vivid picture of mysterious and grandiose snowstorm, gradually becomes more frightening. The sound gamut, based on the consonant [b], symbolizes winter as well as the tragic whiteness of death. "Venchalniy chas!
Luchistaya zima / Chrustalnye raskryla terema / Beleyet lebed v nebe golubom, / I beliy khmel vzmetayetsya stolbom" ("Venchanie") [1, p. 96]. Winter is time after death and before the revival. This period is not present in human life but it is displayed in the life of nature, what seems to be close to the unearthly world.

The sound expressiveness, in V. Zhyrmunskiy's opinion, "can be increased by means of the repetition of the same stressed vowels. This phonetic phenomenon is called the harmony of vowels, which creates the certain melody, built in the necessary tone." [10, p. 171]. Harmony, based on the vowel $[u]$, can be met in many Baltrushaitis' poems. The aim of such phonetic device is to clarify the image as well as to take it to some unexplored depths, to some vague alluring mysteries. "B $u$ dto $\mathrm{s}$ toskoy po $u$ trachennym dnyam / Kto-to po drevnim gl $u$ khim stupenyam, / Рostupy $u$ gruznoy idet $\mathrm{v}$ glubin $u$, / Nizhe, vsyo nizhe, - vo tm $u$ v tishin $u$ " ("Mayatnik") [1, p. 98]. Lyrical character of the poem comes back to the bottom of time, the abyss of primacy. The accumulation of the vowel $[\mathrm{u}]$ accompanies the motif of descend. The harmony of $[u]$ sounds like strokes of mysterious pendulum in deserted boundless space.

The repetition of the vowel $[\mathrm{u}]$ can be used in onomatopoeic words for reproducing sounds of reality. The chime of clock or pealing of bells can be often met in Baltrushaitis' artistic world. "Zychno i skorbno, $u$ dar za $u$ darom, / Miru usn $u$ vshem $u$ kolokol pel... / Tochno nabat pered blizkim pozharom / Dolgo i gulko gudel" ("Kolokol") [1, p. 86]. The instrumentation is combined with dactylic rhythm, syntax and composition of the poem.

Conclusions and prospects of further investigation. The analysis of Baltrushaitis' poetry shows the high level of his poetic culture as well as his ability to reveal the slightest shades of word meaning. All kinds of sound expressiveness are aimed at creating the original emotional colouring of Baltrushaitis' lyrics. The instrumentation takes part in forming and developing the lyrical plot of most poems. The images, motifs and themes of poetry are in strict balance with phonetic expressive means which are often neutralized by clear and simple composition. The specific logics of poetic narration seems to subordinate the rhythmic pattern and the instrumentation of the poems which sound light, simple and even ascetic but as a rule, ponderably and completely.

The further research in this area is to be devoted to the analysis of syntactic expressive means and stylistic devices in Yurgis Baltrushaitis' artistic world in the context of the Russian Symbolist poetry. 
References:

1. Балтрушайтис Ю. Дерево в огне. Вильнюс : Vaga, 1983. 319 с.

2. Бальмонт К. Избранное: Стихотворения; Переводы; Статьи. Москва : Худож. лит., 1983. 750 с.

3. Белый А. Стихотворения. Москва : Книга, 1988. 575 с.

4. Блок А. Собрание сочинений: в 8 томах. Т.1. М.-Л. Гос. изд. худ. лит., 1960. 715 с.

5. Брюсов В. Звукопись Пушкина. Ремесло поэта: статьи о русской поэзии. Москва : Современник, 1991. C. $168-187$.

6. Гаспаров М. Поэтика «Серебряного века». Русская поэзия Серебряного века. 1890-1917. Антология. Москва : Наука, 1993. С. 178-192.

7. Гербстман А. Звукопись Пушкина. Вопросы литературы. 1964. № 5. С. 178-192.

8. Дауетите В. Юргис Балтрушайтис. Вильнюс : Vega, 1983. 326 с.

9. Епишева О. Скрябин и его музыка в стихах поэтов-символистов. Русская культура в текстах. Образах и знаках. Киров. 2009. С. 137-145.

10. Жирмунский В. Теория литературы. Ленинград : Наука, 1977. 560 с.

11. Иванов В. Юргис Балтрушайтис как лирический поэт. Русская литература XX века. Москва : Республика. С. 374-380.

12. Неженец Н. Русские символисты. Москва : Знание, 1999. 64 с.

\section{ЩербиНа В. В. ФОНЕТИЧНІ ВИРАЗНІ ЗАСОБИ ЯК ОСОБЛИВІСТЬ ПОЕТИЧНОГО СВІТУ ЮРГІСА БАЛТРУШАЙТІСА В КОНТЕКСТІ РОСІЙСЬКОЇ СИМВОЛІСТСЬКОЇ ПОЕЗІЇ}

Статтю присвячено аналізу фонетичних виразних засобів у поетичному світі Юргіса Балтрушайтіса. Тенденція до абстрагування та розмивання семантичного значення слова зумовила особливості використання виразних засобів у поезії символістів. Тематика, мотиви, образи та стилістичні прийоми у творах Балтрушайтіса є віддзеркаленням філософських та естетичних поглядів поета.

Мета статті - визначити особливості використання фонетичних виразних засобів у ліриці Балтрушайтіса та встановити їхню роль у художньому світі поета. Однакові емоції та настрій можна відчути в багатьох віршах поета. Доведено, що важливу роль у створенні своєрідного емоційного колориту відіграє оригінальне звукове інструментування. Величезні образи, що оточують людину в поетичному світі Балтрушайтіса, потребують специфічних звукових образів.

Інструментуванню ранніх творів притаманне частевикористання алітераціїта звуконаслідувальної лексики. Алітерація може мати форму фонетичної анафори та фонетичної епіфори. Показано, що фонетична анафора використовується для створення єдиної поетичної тональності та висвітлення психологічного конфлікту між природою та людиною. У лірииі Балтрушайтіса фонетична епіфора спрямована на акцентування чіткого та виразного ритму. Кінцеві приголосні, щзо повторюються, беруть участь у розвитку ліричного сюжету, створюючи певний ліричний настрій і тон поетичного твору. Таке звукове інструментування може змінити ритмічну модель ліричної розповіді, водночас додати енергії та пришвидшити темп віршу.

Аналіз художнього світу Балтрушайтіса свідчить про те, що такі види звукових повторів, як рондо та зевгма, використовуються для виконання естетичної функиї та створення симетрії віриу. Більш складні форми алітераиії та ії розкладення беруть участь у формуванні та розвитку ліричного сюжету багатьох поетичних творів.

Доведено, щуо в лірииі Балтрушайтіа звукова гамма використовується для створення образів природи. Мотиви та теми поезії перебувають у певному балансі з фонетичними виразними засобами, які нейтралізуються чіткою та простою композичією віршів. Ритмічний модуль та інструментування поетичних творів підпорядковані логіиі поетичної розповід $i$.

Ключові слова: алітерачія, анафора, епіфора, інструментування, гамма, лірика. 